\title{
A Modification of UNO Games: "Chemuno Card Games (CCG)" Based on "Chemistry Triangle" to Enhance Memorization of the Periodic Table
}

\author{
Ira Mahartika ${ }^{1, *}$, Neti Afrianis ${ }^{1}$, Heppy Okmarisa ${ }^{1}$, Niki Dian Permana Putra ${ }^{2}$, Diniya ${ }^{2}$, \\ Aldeva Ilhami ${ }^{2}$, Neni Hermita ${ }^{3}$ \\ ${ }^{1}$ Pendidikan Kimia, Universitas Islam Negeri Sultan Syarif Kasim Riau, 28468, Pekanbaru, Indonesia \\ ${ }^{2}$ Tadris IPA, Universitas Islam Negeri Sultan Syarif Kasim Riau, 28468, Pekanbaru, Indonesia \\ ${ }^{3}$ Pendidikan Guru Sekolah Dasar, Universitas Riau, Pekanbaru, 28468, Indonesia
}

Received September 28, 2020; Revised December 4, 2020; Accepted December 13, 2020

\section{Cite This Paper in the following Citation Styles}

(a): [1] Ira Mahartika, Neti Afrianis, Heppy Okmarisa, Niki Dian Permana Putra, Diniya, Aldeva Ilhami, Neni Hermita, "A Modification of UNO Games: 'Chemuno Card Games (CCG)' Based on 'Chemistry Triangle' to Enhance Memorization of the Periodic Table," Universal Journal of Educational Research, Vol. 8, No. 12B, pp. 8411-8419, 2020. DOI: 10.13189/ujer.2020.082647.

(b): Ira Mahartika, Neti Afrianis, Heppy Okmarisa, Niki Dian Permana Putra, Diniya, Aldeva Ilhami, Neni Hermita (2020). A Modification of UNO Games: "Chemuno Card Games (CCG)" Based on "Chemistry Triangle" to Enhance Memorization of the Periodic Table. Universal Journal of Educational Research, 8(12B), 8411-8419. DOI: 10.13189/ujer.2020.082647.

Copyright $\bigcirc 2020$ by authors, all rights reserved. Authors agree that this article remains permanently open access under the terms of the Creative Commons Attribution License 4.0 International License

\begin{abstract}
An in-depth knowledge of the periodic table is one of the most fundamental keys to understand the basic principles of chemistry. Memorizing and understanding the systemic chemical elements is one optional strategy to study the position of each element in the periodic table. However, memorization strategies are generally tricky for students and are not "long term memory". Therefore, it is necessary to have alternative learning that can help understand chemical elements with "long term memory." In this case, the researchers present a modification of the UNO card game called "Chemuno" with the advantages of combining a chemistry triangle approach that implemented chemicals in daily life. Such formulated game is carried out to kindly understand elements of the periodic table and recognize the groups and periods of each element. The development of the current research uses the 4D model with restrictions on the development stage. The game "Chemuno-based Chemistry Triangle" is thereby declared valid with a percentage of $92.5 \%$ and practically with a percentage of $96.86 \%$. The use of such game is limited to schools used as trial sites yet it can be used in other schools with the similar students' characteristics.
\end{abstract}

Keywords Learning Media, Chemistry Card Games, UNO Games, Chemistry Triangle, Multiple Representation

\section{Introduction}

The "Chemuno" card game introduces and explores variations in chemistry learning, especially in elements of the periodic table. The idea come from a UNO card modified for chemistry learning and collaborated with the "chemistry triangle" approach to better provide a proper understanding effect on the implementation and real picture of chemical elements in everyday life. The current research leads to the type of non-digital games. The reason is that researchers want a game that can improve communication and social interaction between fellow players and can be applied anywhere without the use of maximum facilities. Based on the results of a journal study conducted by Vicente Marti-Centelles and Jenifer Rubio-Magnieto who designed a chemical game with the UNO card system on elements of the periodic table, this game demonstrates another way of understanding 
chemical elements [1]. Interest in such formulated game is getting bigger, the reason is, in 2014, the game gets viral among students and is mostly played in leisure time. From this study, researchers are therefore interested in developing a UNO game in chemistry subjects thus students can possess variations in learning and can improve their communication and interaction. However, the difference between this study and study of Vicente Marti-Centelles and Jenifer Rubio-Magnieto is that the authors add a "Chemistry Triangle" approach to the game. This is very different and is unique in this study.

The chemistry triangle or also known as multiple representations is a chemical approach that discusses 3 levels of chemical images, namely macroscopic, submicroscopic and symbolic. This is consistent with Johnstone's explanation, that the chemistry triangle consists of three aspects that are interrelated and will be able to improve students' understanding of all chemical concepts which are described as triangles, namely macroscopic, submicroscopic, and symbolic [2]. The macroscopic aspect is a phenomenon that can be observed (seen, felt, and smelled). Stieff explained that the chemistry triangle aspect, namely the submicroscopic aspect, is the unobservable phenomena study, such as: atoms, molecules, ions, and structures. Symbolic aspects are symbols used to communicate chemistry, such as: chemical notations or formulas, mathematical equations, and graphics. These three aspects have a contribution in improving the quality of students' understanding which will be reflected in their mental models when studying chemistry [3]. The implementation of the chemistry triangle approach in the field of chemistry in terms of research conducted by Milenković provides positive findings that using multiple representations increases student performance and contributes to a reduction in cognitive load [4]. Furthermore, Fahmy gave good findings about the systemic chemistry triangle approach in creating an active learning environment that allows students to acquire high mental skills, correct cognitive, positive attitudes towards chemistry and the environment [5]. Recent research is currently also conducted by Petillion which provides findings that Johnstone's triangle contributes positively to students' conceptual understanding [6]. Therefore, from the research references, the chemistry triangle approach is obtained, which is very relevant if it is implemented in chemistry subject and has a positive contribution.

The focus of the chemical material to be researched is elements of the periodic table, such as sub-sections of the atomic material structure and elements of periodic system. The selection of the atomic structure and periodic elemental system material is based on the experience of teaching researchers as a teacher from 2014-2018 that the students' ability to understand the material was very low, only $35 \%$ had memorized the periodic table well. Then, many students did not know the shape of the molecules (submicroscopic), the real form (macroscopic) and implemented elements in everyday life.

The periodic table is an essential core material for learning and understanding the nature of chemical elements. This is particularly correct, based on the study of the $\mathrm{K}-13$ curriculum revision, this material is on the second topic to be taught after the material of the chemistry of science in class X semester 1. And therefore, the material is primary that should be comprehensively understood and is mainly crucial to understand by learners to study chemistry at the further stage. If you do not understand the material, it will affect the constraints in understanding and learning the next material such as chemical bonds, reduction and oxidation reactions, compound name, reaction equation, stoichiometry, and material in class XI and XII for those who take the science department. Therefore, understanding the elements of periodic table is the key to study chemistry, hence learners are required to understand and memorize all chemical elements.

Based on the above statement, the researcher evidence whether the statement is in accordance with reality as well as what obstacles are experienced in studying the atomic structure material and the periodic system of elements in real in the field. First, there are obstacles for class XI students in making chemical reactions on acid-base concept, buffer solutions, salt hydrolysis and chemical equilibrium. The basic to make chemical reactions is knowing the ions of each element which can be seen on the periodic table of the elements and their electron configurations. Second, there are obstacles for class X students on the atomic structure concept and the elemental periodic system, namely students tend to memorize the names of chemical elements with an element song and short terms combined into complete sentences without knowing the atomic number and chemical symbols properly. Not only that, the elemental memorization system is only limited to group A and for class B memorization is left to students, this of course makes students lazy to memorize if not guided by the teacher. Then, students feel confused to understand the electron configuration concept and determining the period and group of an element in the periodic table and do not know the submicroscopic and macroscopic forms of each element. Problems were obtained based on the teaching experience of researchers in three senior high school in Padang City in class X and XI in the 2014/2015 academic year. Therefore, researchers feel the need to provide a variety of learning on the periodic table of elements with the aim that students are able to understand and memorize the periodic table of elements quickly and accurately.

The problems that occurred in the 2014/2015 academic year in the city of Padang was not adequate to be the basis for researchers to develop a game product called UNO chemistry on the atomic material structure and elements of the periodic system. On account of such obvious matters, 
the researchers were therefore interested to provide the similar evidences related to constraints on the atomic material structure and elements of the periodic system in Pekanbaru. Firstly, there were similar obstacles to the above matters. Generally, the learning process on the periodic table only focused on the memorization system with a short term made of one sentence intact. Secondly, the average students considered the chemistry to be abstract material and it was necessary to highlight a real picture of what exactly constituted beyond the environment. Hence, students could understand more regardless chemistry. Thirdly, the teachers' way of delivering the chemical material had not been varying, they only focused on the use of textbooks with conventional learning methods, discussions, and presentations. The reason was described that they did not have the time to develop different learning media. The object of the initial study that the researchers conducted was in class XI students who studied the material of the atomic structure and the periodic system of elements. The problems found were based on interviews of teachers and students (class XI) in 6 (six) SMA/MA in Pekanbaru in the academic year 2018/2019. Therefore, looking at the prior study conducted in Padang in 2014 and in Pekanbaru in 2018 , it continued to have the similar problem that shall be immediately resolved and provided a solution for five years.

The development of the UNO chemical game on the atomic structure material and the periodic system of these elements will be more interesting and useful if it collaborates with the "Chemistry Triangle," which provides a real picture of the chemical elements that we can see in everyday life. This is undoubtedly an added value that has never been developed and researched previously in the UNO chemistry game for chemistry subjects and strengthened by the study of literature that the reseacrhers have received from the range of 2015-2019 years. Spandler developed a UNO chemistry game called "Mineral Supertrumps" in the mineralogical subject matter [7]. Da Silva-Júnior et al. developed an interactive chemistry game through the computer according to the UNO card concept called "Stereo game" on stereochemical material [8]. Erlina et al developed the game called "The VSEPR Game" using molecular cards and building a chemical molecule to improve students' understanding of molecular geometry material [9]. Brydges and Dembinski developed the game called "Catalyze" with board games that successfully enhance students' understanding on chemistry [10].

Based on results obtained in this line of research, the researchers are therefore argued that there is still no UNO chemistry game with the concept of "Chemistry Triangle" approach developed on atomic structure material and elements of the periodic table, hence it becomes a novelty and strength of ideas for the researchers to conduct this valuable project. And finally, the ultimate objective of creating this product is to expect students to know and understand the position of elements in the periodic table based on period and classes, and identify chemical elements.

\section{Materials and Methods}

The current research is a type of development research with teachers and students referred as subjects. The sample is carried out using a purposive sampling technique. Data collection techniques employs non-test techniques such as questionnaires and interviews. Primary data in this study from interviews described and questionnaire data processed quantitatively (statistics). The research is conducted in an estimate of June up to November 2019.

This development research carried out with the Four-D (4D) model. There are 4 stages carried out, namely: 1) Define phase, at this stage an analysis needs to be performed to find out the problems contained in learning as well as the use of media needed. In this stage, the collection of information is done through observing the implementation of learning, interviews with chemistry teachers and giving questionnaires to learners. The analysis is also continued on students to obtain the needs of students who are the target of chemical game media users. The results of the analysis of these students are used as consideration in designing and developing chemical game products. Furthermore, curriculum analysis is carried out to study the scope of the material, learning objectives, strategies and learning media chosen as the basis for developing the expected products. The final analysis is related to the concept of determining the material needed in the development of the chemical game media to achieve the competency achievement indicators that have been set. 2) Design phase, at this stage, creates a game format that will be comprehensively designed based on the results obtained at the defining stage, then proceed with the validation of the questionnaire instrument that will be used at the development stage. 3) At this phase, the development phase is the making of the "Chemuno" card game based on the "Chemistry Triangle" and validating the products that have been produced to learning media experts and chemical material experts. After the media is valid, it continues with the practicality test with a limited sample.

\section{Results and Discussion}

\subsection{Defining Phase}

Based on the results of the needs analysis at the defining stage, $57.14 \%$ of schools obtained data giving positive feedback on the needs of the chemical game 
media [11]. Desired needs lead to games in an electronic and non-electronic form with the notes that the media can be utilized and provide a good understanding of the material. Researchers tried to conduct an internal interview with seven individual chemistry teachers to see the learning methods on the material periodic table of the elements that had been implemented. Result of interview can be seen in Table 1 .

Table 1. Interview questions to the teacher about the methods used in the periodic table of elements concept

\begin{tabular}{|c|c|}
\hline Number & Interview questions \\
\hline 1. & $\begin{array}{c}\text { Are there any obstacles for students in understanding } \\
\text { and memorizing the periodic table of elements? }\end{array}$ \\
\hline 2. & $\begin{array}{c}\text { How to memorize and understand the periodic table of } \\
\text { elements that has been applied to students }\end{array}$ \\
\hline 3. & $\begin{array}{c}\text { Is the method or media used effectively and helps } \\
\text { memorize and understand the periodic table of } \\
\text { elements? }\end{array}$ \\
\hline 4. & $\begin{array}{c}\text { Have any recent innovations been made in studying the } \\
\text { periodic system of the elements concept? }\end{array}$ \\
\hline
\end{tabular}

From the questions above, the results of the interviews were obtained in oral form and the authors recorded all the important things related to the teachers' answers in detail and were explained by descriptive techniques.

Table 2. Recapitulation of interview results about methods used on the material of elements on the periodic table

\begin{tabular}{|c|c|c|}
\hline Number & Respondents & Teacher's response \\
\hline 1. & School A & $\begin{array}{c}\text { Memorization of chemical } \\
\text { element names }\end{array}$ \\
\hline 2. & School B & $\begin{array}{c}\text { Memorization of chemical } \\
\text { element names }\end{array}$ \\
\hline 3. & School C & $\begin{array}{c}\text { Memorization of chemical } \\
\text { element names }\end{array}$ \\
\hline 4. & School D & $\begin{array}{c}\text { Memorization of chemical } \\
\text { element names }\end{array}$ \\
\hline 5. & School E & $\begin{array}{c}\text { Memorization of chemical } \\
\text { element names }\end{array}$ \\
\hline 6. & School F & $\begin{array}{c}\text { Memorization of chemical } \\
\text { element names }\end{array}$ \\
\hline 7. & School G & $\begin{array}{c}\text { Memorization of chemical } \\
\text { element names }\end{array}$ \\
\hline
\end{tabular}

From such formulated data, learning on the periodic table of elements has only been memorized. The type of memorization used can be through singing and making sentences so that they can be arranged into one unit that is easy to understand. The memorization system can only be done on group A elements, while class B teachers instruct students to memorize independently without guidance from the teacher. Based on this, of course, it is very difficult for students to memorize the elements of group B independently and it will take a lot of time. In addition, the teacher believes that there are still no other methods that can support memorizing the periodic table and the average student does not know the implementation of all these elements in daily life. So, based on the results of this preliminary analysis, it is very relevant to the researcher's idea of creating a fun chemical game media that can make students understand the chemical elements of groups A and $\mathrm{B}$, then adding the chemistry triangle approach, it is very necessary to give it to students so that they are not just memorize but understand the macroscopic and microscopic form of an element. So, learning can be more effective and meaningful.

The results of the research at the define stage obtained are also the researcher's experience strengthening of being a chemistry teacher from 2014-2017 as well as the results of the preliminary research conducted in 2018-2019 which until now teachers still use the memorization method. Therefore, the idea of the researcher in making a chemistry game based on the chemistry triangle on the periodic table of these elements can contribute well in providing variations in learning that so far have only been done with a route system.

In this study, focused on groups of elements A and B, because researchers limit this research to make it easier to understand and not take a long time to play. Based on the limitations of this study, other researchers to continue this study are advised to make chemical play on the inner transition metal parts, namely lanthanides and actinides.

\subsection{Design Phase}

At this phase, a validation questionnaire was made for learning media experts and chemistry experts, interview sheets, useful questionnaires for teachers and students, and the media's initial design. The process of designing the media is adjusted to the results of the needs analysis that has been done. All types of research instruments carried out logical validity (content and construct) with expert judgment so that research results can be accounted for and can measure variables appropriately. This "Chemuno" playing card media is complemented by the addition of the "Chemistry Triangle" learning approach, known as multiple chemical representations consisting of sub-microscopic, macroscopic and symbolic aspects.

Sub-microscopic aspects of studying phenomena cannot be observed in plain sight, such as atoms, molecules, ions, and structures. The macroscopic aspect is a phenomenon that can be observed with the five senses. Symbolic aspects are symbols or languages used to communicate chemistry, such as chemical notations or formulas, mathematical equations, and graphs. These three aspects can contribute to the quality of students' understanding that will be reflected in their mental models when explaining a phenomenon [3]. Another explanation is reinforced by Treagust, which states that students' ability to understand the role of these three levels of representation and to link them from one level to another is an essential aspect to produce understandable chemical explanations [12]. Researchers aim to add this approach so that students better understand the implementation of each chemical element that is very close to everyday life as well as its mineral form in real terms.

This game card was designed using the application "Adobe Photoshop Creative Suite 6" with a simple and attractive design. Some chemical card design processes was depicted in the image below: 


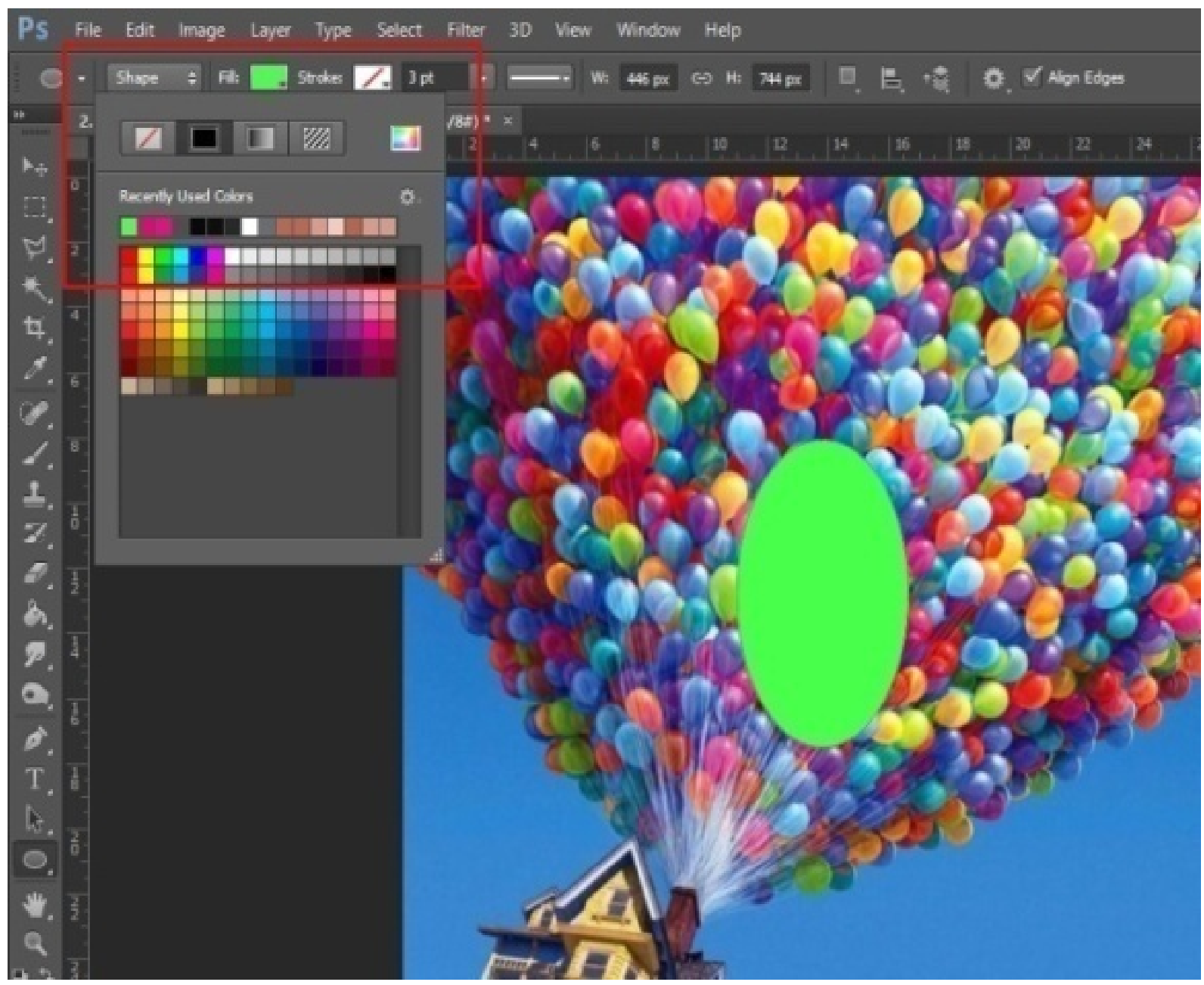

Figure 1. The "Chemuno" card design process using the Adobe Photoshop Creative Suite 6 Application

\subsection{Development Phase}

The "Chemuno" card game was designed then tested by an expert validity consisting of 6 people. The learning media validators were two people with S3 education background, two material validators with Doctoral background in pure chemistry and chemistry education, and two chemistry teachers with chemistry S1 and S2 backgrounds. The following is an explanation regarding the game card "Chemuno" based on "Chemistry Triangle":

\section{Game Card Introduction}

Chemuno is a game adapted from UNO cards. The UNO game is still often played to spare time. The chemuno card package consists of 81 chemical elements cards and 5 additional cards called chemuno-act cards. Chemuno cards use quality paper materials that are durable, colorful, easy to read and have additional application information elements in everyday life. The game is visually expected to attract the attention of students and be able to understand the periodic table of the elements well.

On each card element, Chemuno has a chemistry triangle approach, which is information related to the atomic number of elements, elemental mass number, molecular element description, detailed mineral element description, and element implementation in daily life. Each chemuno-act card is associated with symbols in chemistry lessons, namely "Kartu Ionisasi Unsur (-1 and -2)"/draw to cards, "Kartu Kesetimbangan Kimia"/reverse cards, "Kartu Mendeleev" (discoverers of the periodic table of elements) / wild cards. The card shape can be seen in (figure 2A, 2B, 2C) below: 


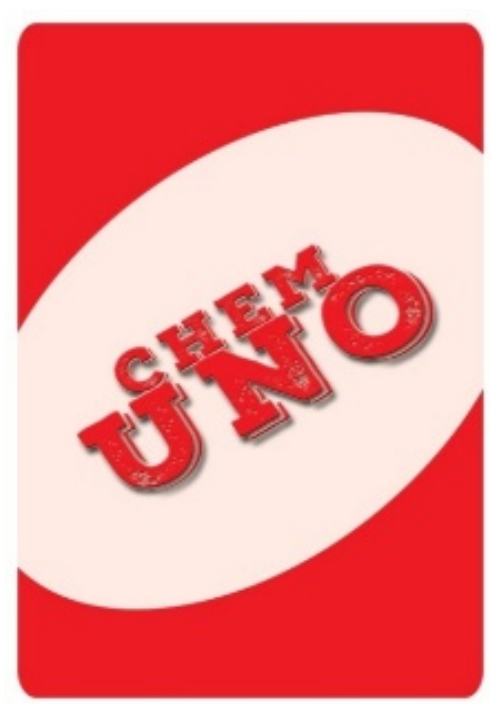

A

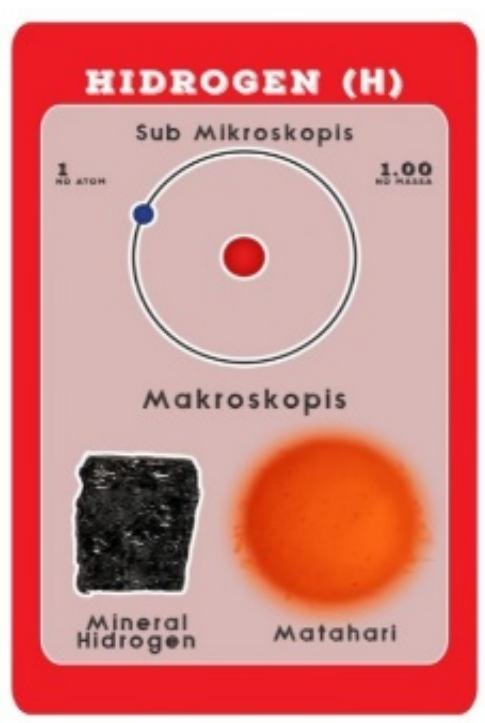

B

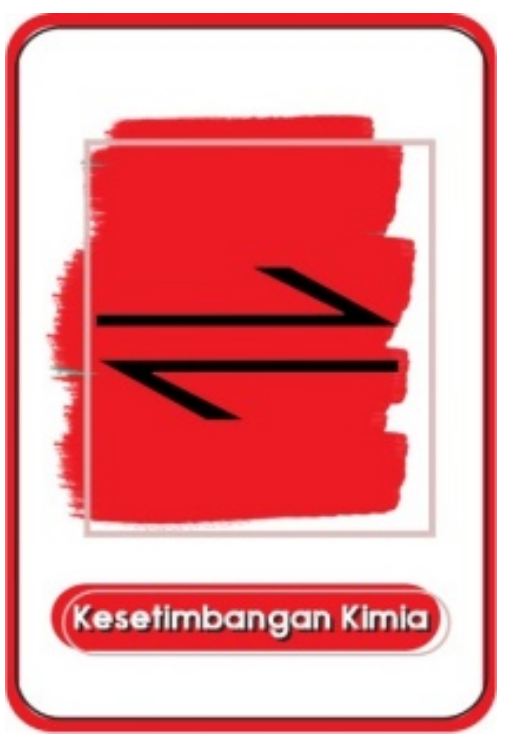

C

Figure 2. (A) Chemical Element Card (Rear View), (B) Chemical Element Card (Front View), (C) One of the Chemuno-Act Cards
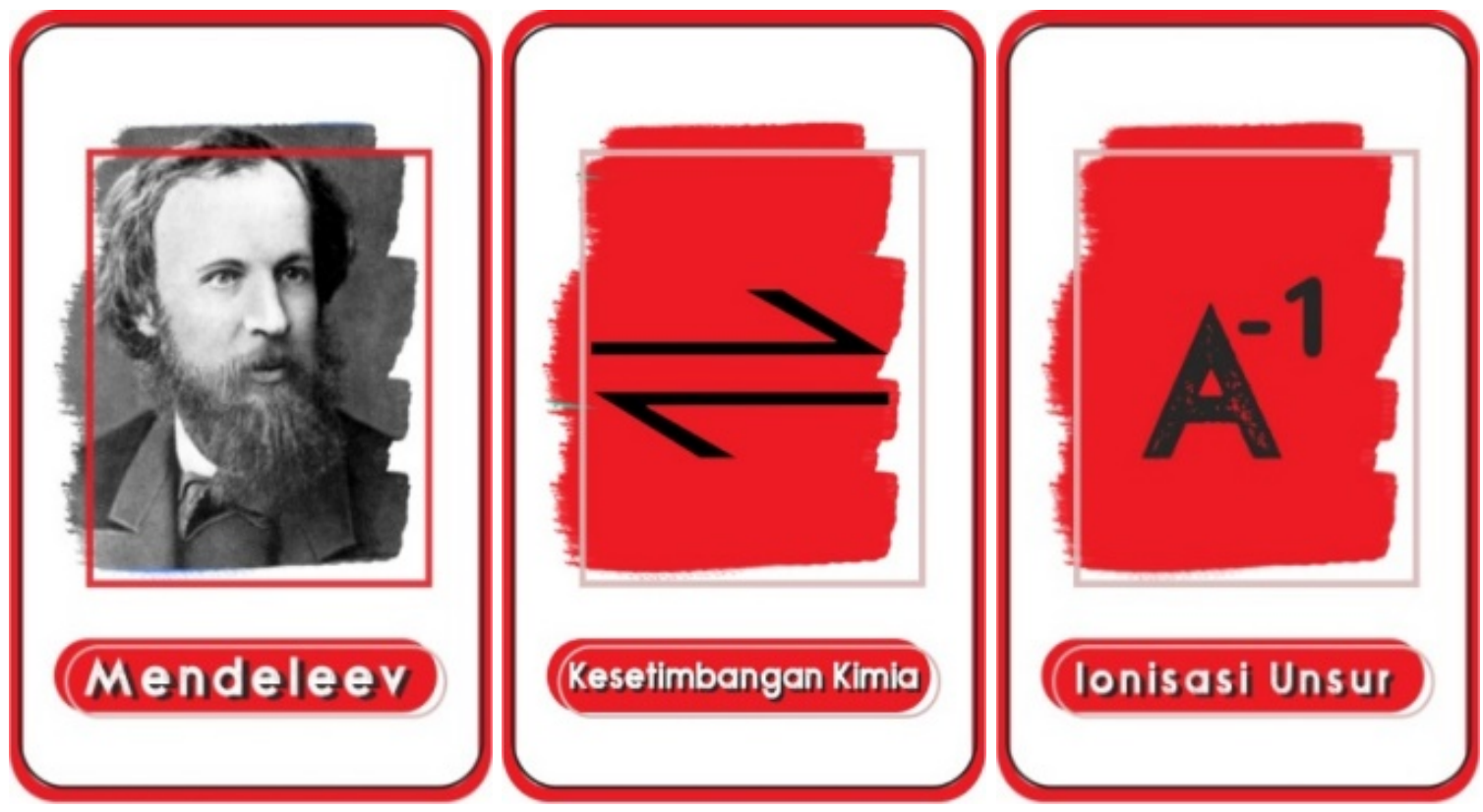

Figure 3. Some Chemuno-act cards

Explanation of the Functions of Chemical Game Cards

2-10 players can play this game. The main objective of this game is to improve students' ability to understand the periodic table of elements. The total number of cards is 108 cards, namely 81 chemuno-element cards except lanthanide and actinide groups, 27 chemuno-act cards (4 "Kartu Stop"/skip cards, 5 "Kartu Kesetimbangan Kimia"/reverse cards, 8 "Kartu Mendeleev"/wild cards and 10 "Kartu Ionisasi Unsur (-1 and -2$)$ ")/draw to card, the explanation of the card is as follows:

Kartu Stop: If a player issues this card, the next player is skipped, so the next player loses the chance to remove it.

Kartu Kesetimbangan Kimia: The card marked $(\rightleftarrows)$ has the function of changing the game's direction, for example, the one originally clockwise to counterclockwise.

Kartu Mendeleev: The card with the portrait of a Mendeleev allows the player to freely select a new period or group for the next player. This card can also be used at the beginning of the game. The card was designed as a tribute to Dmitri Mendeleev as the inventor of the element's periodic table.

Kartu Ionisasi Unsur: When this card is played, it requires the next player to take on the draw pile of two cards or one card according to the ionization symbol indicated on the card. 


\section{How to Play Chemistry Game Cards}

Step 1: The game starts by choosing a "dealer." A dealer is a person who shuffles cards randomly.

Step 2: After the cards are shuffled (see figure 4A), the dealer gives eight cards to each player. The number of cards given can be adjusted to the conditions (see figure 4B).

Step 3: Every player is not allowed to show his card to others. The remaining cards are placed face down and closed, which will function as a draw pile.

Step 4: The game starts from the player to the left of the dealer by giving out the chemical element card. The player who gives the card must say the atomic number and the name of the element, the period and group of the element, and the example of implementation of the element in daily life. For example, if a player issues a Boron (B) card, then the player has to convey to another friend with the sentence "element Boron, atomic number 5, located in group IIIA period 2, the implementation of Boron (B) can be seen in insect poisons. Verbal articulation is designed to improve student memory of chemical elements; such articulation is a must for all players.
Step 5: The next player (still from the left) releases the corresponding card from the card played by the previous player based on group or period. As an example, when the card being played is the element Boron (symbol: B, group IIIA, period 2), the other player can issue a carbon card that has a period similarity with Boron (symbol: C, period 2, group IVA) or Aluminium that shared the same class with Boron (symbol: Al, class IIIA, period 3).

Step 6: The game continues in a clockwise sequence. The requirements in the composition of the elements must be sequential, for example, $\mathrm{B}, \mathrm{Al}, \mathrm{Ga}, \mathrm{In}, \mathrm{Tl}$ for group or $\mathrm{Li}, \mathrm{Be}, \mathrm{B}, \mathrm{C}, \mathrm{N}, \mathrm{O}, \mathrm{F}, \mathrm{Ne}$ for a period sequence (see figure $4 \mathrm{D})$. If the player does not have an element card to be issued during the process, then one card can be stacked with a draw pile card or may be issued a chemuno-act card if there is one.

The key to the game is who completes the card sequence according to the period or group is the winner. So the game requires a strategy of how to sort cards by period and group quickly. This game has a leeway in the game that every player has a $3 \mathrm{x}$ chance to see the periodic table of elements with permission from the dealer. The game scheme can be seen in (figure 4) below:

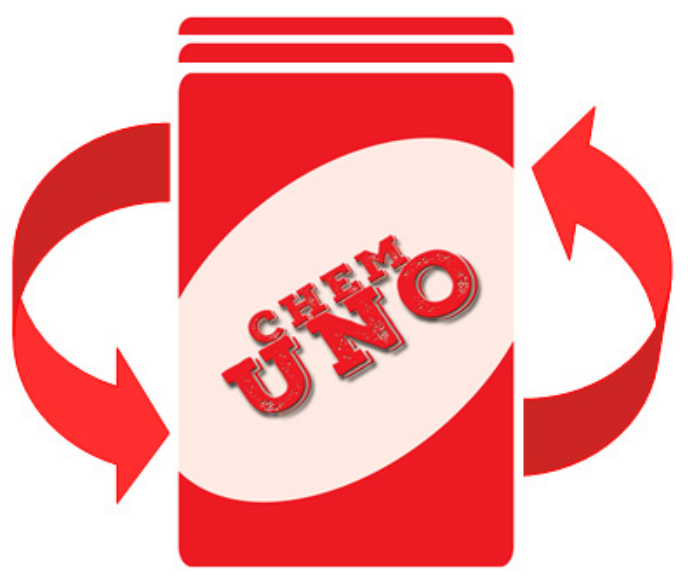

(A)
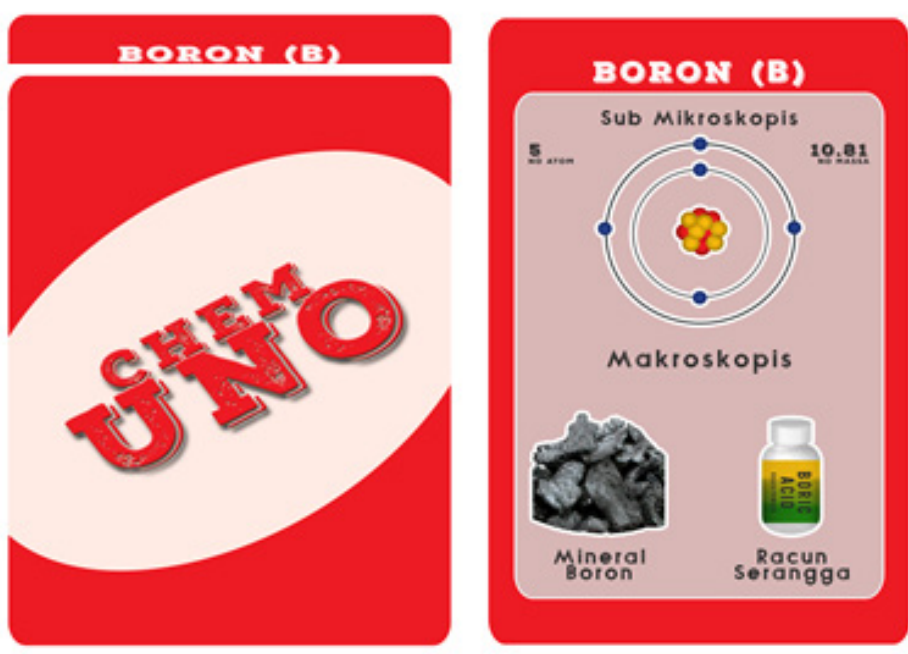

(B) 


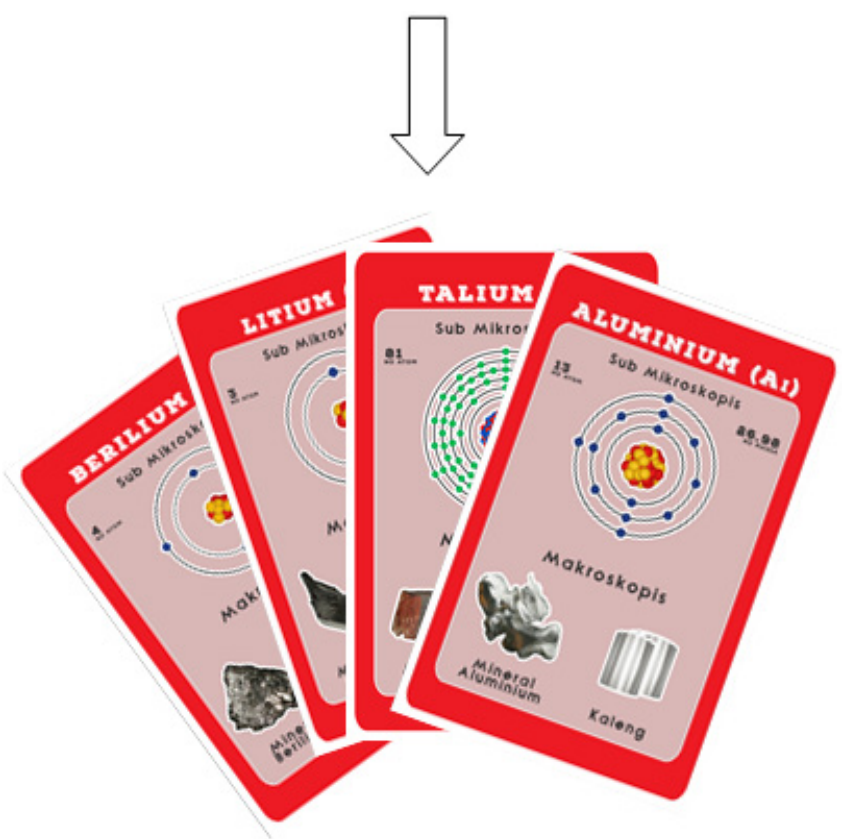

(C)
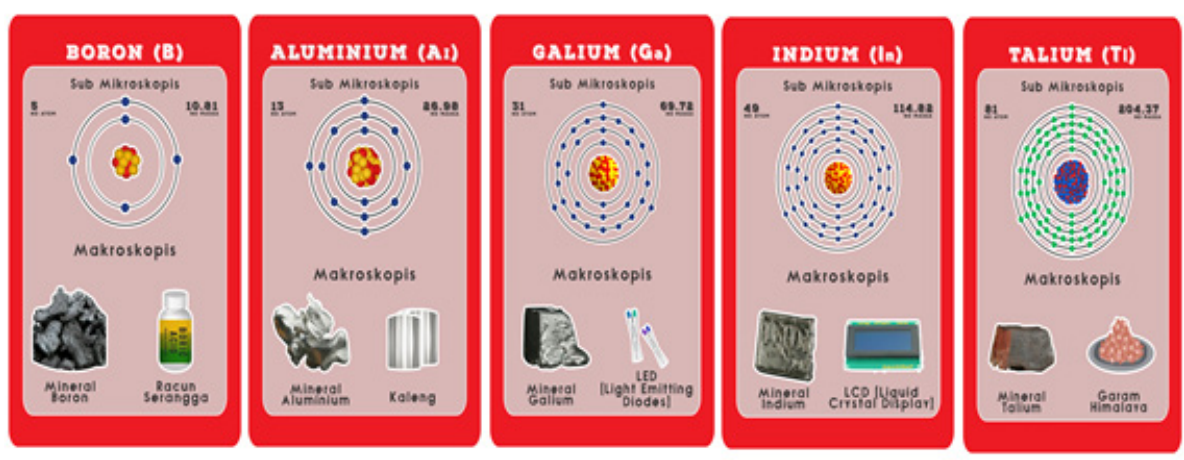

(D)

Figure 4. Game scheme "Chemuno card games" based on "chemistry triangle."

\section{Results of Validity and Practicality}

The validity results obtained from media experts and material experts are equal to $92.5 \%$ with the criteria "very valid". After the product is valid, a practicality test was conducted on the teacher and students using a questionnaire and interview instrument. The practicality sample is only limited to small group evaluation in 1 school in Pekanbaru. Based on practicality test results obtained data, the card game "chemuno card game" was easy to use, has attractive, clear and understandable game rules, was able to motivate and create the enthusiasm of students to study chemistry, determine new knowledge related to chemical elements in the form of submicroscopic-macroscopic-symbolic, has advantages in the application of chemical elements in daily life and can hone students' understanding of the determination of group and period of an element in group A and group B. Students feel that the "chemuno" card is very useful because they have never known how to fast in determining the group and period, especially group B and rarely given additional knowledge related to the application of chemical elements in real life. Practical chemistry game "chemuno card game" is already practicing with a value of $96.86 \%$, according to Nieveen's opinion, which states that a learning device is practical if the device can be used easily by teachers students in learning [13]. 


\section{Conclusions}

Based on result and discussion, the researchers would simply like to draw the attention once more to the fact that Chemuno card game has fulfilled the criteria of valid products in terms of content and construction and assessment of the validators. This game also fulfills practical criteria in terms of presentation and attractiveness, ease of use, legibility, and required time. Most importantly, the strength of such "chemuno" card game lies in the "chemistry triangle" approach, which is rarely implemented in a chemical game. The latest idea of researchers is to collaborate on hits game UNO cards with the approach of chemistry triangle that presented simply and clearly and able to assist students in understanding the group's determination and the period of chemical elements. The use of "Chemuno" card games is limited to schools that are the only test locations yet it can be used in other schools with the similar students' characteristics.

The authors offer other researchers to be able to innovate in making variations of other chemical game media, then, to make special games for the transition metal groups in (lanthanides and actinides) and to modify these games in the form of interactive multimedia or digital-based.

\section{Acknowledgements}

The researchers would like to express the deepest appreciation to the Ministry of Religious Affairs, in this case, the Director of Islamic Religious Higher Education (DIKTIS) has provided the opportunity for PTKIN and PTKIS lecturers to improve the quality of education through research, scientific publications, and community service. Furthermore, the researchers are extremely grateful to UIN Suska Riau and LPPM UIN Suska Riau for generous support and funding assistance to researchers to conduct research activities as the primary duties as lecturers to figure out the Tri Dharma of Higher Education. Furthermore, the researchers would like to express sincere gratitude to the Principal who has provided the opportunity to conduct such research, and also sincere thanks to the Teachers and Students who have contributed in providing detailed and valid data related to this research, as well as to the internal team of the researchers, without their encouragement, this paper would not have materialized.

\section{REFERENCES}

[1] V. Martí-Centelles and J. Rubio-Magnieto, "ChemMend: A card game to introduce and explore the periodic table while engaging students' interest," J. Chem. Educ., vol. 91, no. 6, pp. 868-871, 2014.

[2] A. H. Johnstone, "Chemical Education Research: Where from Here?," Univ. Chem. Educ., vol. 4, no. 1, pp. 34-38, 2000 .

[3] M. Stieff, "Connected chemistry - A novel modeling environment for the chemistry classroom," J. Chem. Educ., vol. 82, no. 3, pp. 489-493, 2005.

[4] D. D. Milenković, M. D. Segedinac, and T. N. Hrin, 'Increasing high school students' chemistry performance and reducing cognitive load through an instructional strategy based on the interaction of multiple levels of knowledge representation," J. Chem. Educ., vol. 91, no. 9, pp. 1409-1416, 2014

[5] A. F. M. Fahmy, "Uses of systemic approach and chemist's triangle in teaching and learning chemistry: Systemic Chemistry Triangle [SCT] as a teaching \& learning strategy," African J. Chem. Educ., vol. 6, no. 2, pp. 69-95-95, 2016.

[6] R. J. Petillion and W. S. McNeil, "Johnstone's Triangle as a Pedagogical Framework for Flipped-Class Instructional Videos in Introductory Chemistry," J. Chem. Educ., vol. 97, no. 6, pp. 1536-1542, 2020.

[7] C. Spandler, "Mineral Supertrumps : A New Card Game to Assist Learning of Mineralogy," vol. 114, pp. 108-114, 2016 .

[8] J. N. Da Silva Júnior et al., "Stereogame: An Interactive Computer Game That Engages Students in Reviewing Stereochemistry Concepts," J. Chem. Educ., vol. 94, no. 2, pp. 248-250, 2017.

[9] Erlina, C. Cane, and D. P. Williams, "Prediction! the VSEPR Game: Using Cards and Molecular Model Building to Actively Enhance Students' Understanding of Molecular Geometry," J. Chem. Educ., vol. 95, no. 6, pp. 991-995, 2018 .

[10] S. Brydges and H. E. Dembinski, "Catalyze! Lowering the activation barriers to undergraduate students' success in chemistry: a board game for teaching assistants," J. Chem. Educ., vol. 96, no. 3, pp. 511-517, 2019.

[11] I. Mahartika, N. Afrianis, and N. Yuhelman, "Analisis Kebutuhan Chemistry Games (CGs) pada Pembelajaran Kimia di SMA / MA Kota Pekanbaru," vol. 3, no. 1, pp. 35-44, 2020.

[12] D. F. Treagust, G. Chittleborough, and T. L. Mamiala, "The role of submicroscopic and symbolic representations in chemical explanations," Int. J. Sci. Educ., vol. 25, no. 11, pp. 1353-1368, 2003.

[13] N. Nieveen, "Prototyping to Reach Product Quality," Des. Approaches Tools Educ. Train., pp. 125-135, 1999. 